Article

\title{
Exploring Engagement With EU News on Facebook: The Influence of Content Characteristics
}

\author{
Tobias Heidenreich $^{1,2, *}$, Olga Eisele ${ }^{2}$, Kohei Watanabe ${ }^{3}$, and Hajo G. Boomgaarden ${ }^{2}$ \\ ${ }^{1}$ WZB Berlin Social Science Center, Germany \\ 2 Department of Communication, University of Vienna, Austria \\ ${ }^{3}$ Waseda Institute for Advanced Study, Japan \\ * Corresponding author (tobias.heidenreich@wzb.eu)
}

Submitted: 30 July 2021 | Accepted: 3 December 2021 | Published: 17 February 2022

\begin{abstract}
The EU is diagnosed with a participation deficit, rooted in a lack of public communication. While news media are the primary source of information about EU politics, social media have become an important channel for political information. Importantly, social media platforms offer unique opportunities for citizens to engage with information about the EU. Such engagement is under-researched despite users' responses offering valuable information about the potential effects of EU news on public engagement. Therefore, we systematically analyze social media users' engagement with news about the EU. Drawing on the concepts of news values and shareworthiness, we investigate the proximity, conflictuality, negativity, and emotionality of EU news content posted on mainstream media Facebook accounts to explain the variation in reactions, shares, and number of comments. Using semi-supervised machine learning, we analyze articles from the largest newspapers in Austria for the period 2015-2019, along with Facebook users' reactions to them. Results resonate only partly with prior literature, with negativity of EU news leading to more reactions and shares but fewer comments; emotionality, to fewer reactions and shares but more comments; and conflict mainly decreasing user engagement. Concerning proximity, a national angle leads to distinctly more engagement, whereas news about other EU member states and the EU as such do mostly not. Our study contributes to the discussion on how citizens engage with information on the EU and how to promote informed debate on social media through elites' communication.
\end{abstract}

\section{Keywords}

automated content analysis; computational methods; European Union; Facebook; news; social media; user engagement

\section{Issue}

This article is part of the issue "Analyzing Citizen Engagement With European Politics Through Social Media" edited by Pieter de Wilde (Norwegian University of Science and Technology), Astrid Rasch (Norwegian University of Science and Technology), and Michael Bossetta (Lund University).

(C) 2022 by the author(s); licensee Cogitatio (Lisbon, Portugal). This article is licensed under a Creative Commons Attribution 4.0 International License (CC BY).

\section{Introduction}

The EU has been diagnosed with a participation deficit, characterized by the public's general lack of interest in EU affairs, rooted in its low visibility in public discourse and the media, as well as the alleged remoteness and lack of transparency of the EU's political structures (Boomgaarden et al., 2013; Michailidou, 2008). In over a decade of crises, people's interest in EU politics has increased, and so has the EU's media visibility, both however negatively: Public support for the EU has declined in many member states (Baglioni \& Hurrelmann, 2016), empowering Euroskeptic, even nationalist political forces (e.g., Hobolt \& De Vries, 2016). Media coverage has remained highly negative and skeptical (Marquart et al., 2018). Therefore, EU crises have increased political interest in EU affairs (de Wilde et al., 2014), but in the form of Euroskepticism, thus not with more, but rather with less support for European integration. This may seem bad news for the EU in terms of its 
legitimacy. Yet, considering, for example, the notoriously low turnout in EU elections (e.g., Gattermann et al., 2021), more interest in and engagement with EU politics should generally be seen as desirable; after all, democracy lives on the regular feedback from and engagement with its citizens (e.g., Van Deth, 2016).

Regarding possible modes and channels for participation, the past decade has witnessed dramatic changes in how people consume political information and engage with politics owing to the advent of the internet (e.g., Bennett \& Pfetsch, 2018). Social media not only allow the diffusion of information from the political elite (top-down) but also from citizens (bottom-up) and were, therefore, welcomed as a promising new route to fostering participation in the EU'S democratic process (Michailidou, 2008). Indeed, citizens' attention has increasingly shifted toward social media as a disseminator of political information and the main entry point for news consumption (Bode, 2016; Newman et al., 2021; Welbers \& Opgenhaffen, 2019). The academic debate about the EU's democratic deficit, however, does not mirror the increased importance of social media as they remain an under-researched arena of public discourse about and engagement with European politics (but see the works by Michailidou and others for notable exceptions, e.g., Barisione \& Michailidou, 2017). Existing studies (e.g., Bossetta et al., 2017; Fazekas et al., 2021; Galpin \& Trenz, 2019) have provided important insight into citizens' social media engagement in EU politics but have often remained focused on special events such as the EU elections. As a result, we only have limited knowledge about the general dynamics of public engagement with social media content about the EU.

In this study, we investigate users' engagement with news media content about EU politics in particular. As we know from earlier studies, the daily news is often the only source of information about EU politics (e.g., Boomgaarden \& De Vreese, 2016; Boomgaarden et al., 2013; Marquart et al., 2018). By focusing on engagement with social media content produced by professional journalists, we connect the top-down and bottom-up dimensions of public communication about the EU, allowing us to dovetail earlier research. In addition, it remains challenging to trace the actual reception and potential effects of top-down information like news media content on the public, particularly in a multilevel polity like the $\mathrm{EU}$ and an increasingly complex media environment (e.g., Bennett \& Pfetsch, 2018; Hobolt \& De Vries, 2016). Given the centrality of social media as a source of political information (e.g., Welbers \& Opgenhaffen, 2019), user engagement with EU news posted on social media platforms could therefore help to better understand its potential impact on the public awareness and opinion.

We contribute to the literature by providing a comprehensive, large-scale analysis of users' engagement with EU news on Facebook. Our analysis is theoretically embedded in the discussion on news values (Harcup \& O'Neill, 2017) and shareworthiness (Trilling et al., 2017).
We look into the characteristics of EU news content posted on mainstream media accounts for the period 2015-2019 to explain the variation in the number of reactions, shares, and comments a post received. Relying on semi-supervised machine learning, we analyze articles from the 12 largest newspapers in Austria posted on their Facebook accounts along with users' reactions to them. By focusing on a rather small EU member state such as Austria, we were able to conduct a comprehensive analysis including all important newspapers on the country's most popular social media site. Overall, our study contributes to the discussion on how citizens engage with EU politics and promote informed debates on social media through elites' communication.

\section{Engaging With EU News Content on Social Media}

Democracy thrives on the active participation of its citizens, broadly defined as "citizens' activities affecting politics" (Van Deth, 2016, p. 2). The internet has brought about new opportunities for participation: Aside from the more direct forms, such as signing petitions or campaign donations, citizens' active engagement with political news, e.g., writing letters to the editor, but also reacting to or sharing news articles online, has been conceptualized as political engagement (e.g., Vissers \& Stolle, 2014). Thus, political participation also accommodates the new possibilities brought about by the broader process of digitalization. Regarding citizens' engagement, the democratic credentials of the EU have long been contested, resulting in a diagnosis of a participation deficit: This is mirrored in, for example, the notoriously low turnout in elections to the European Parliament, which is only slowly beginning to resemble elections where something is at stake (Gattermann et al., 2021). Therefore, digital communication channels were welcomed as promising ways to promote citizens' engagement in EU politics (Michailidou, 2008).

Yet, research on social media communication is often ambivalent regarding possible effects on democracy and public discourse. On the positive side, the possibility of direct, unedited communication on social media offers space for peoples' ungated participation in public discussions. It thus is "a valuable contribution that adds to the plurality of public opinion formation in the democratic public sphere" (Cinalli et al., 2021, p. 87). On the negative side, however, user comments have often been described as furthering hate speech, being uncivil or at least very negative (e.g., Ekman, 2019; Galpin \& Trenz, 2019), and in that sense destabilizing, rather than enriching public discourse (Cinalli et al., 2021, p. 86). Regarding the EU, social media is indeed considered a promising tool for furthering engagement with the potential to eliminate the borders which still structure the public sphere in the EU (Bossetta et al., 2017). However, social media users' comments on EU news have also been described as overwhelmingly negative and even populist (Galpin \& Trenz, 2019). 
While research regarding EU engagement on social media has often remained focused on the content of social media interactions about EU issues, our study investigates different nuances, guided by the overall question of what characteristics of EU news coverage trigger different forms of online engagement. We distinguish reactions, sharing, and commenting: While the sharing of and commenting on information on social media might be seen as forms of engagement requiring most user commitment compared to reactions (e.g., "like"), the latter are distinctly more common (Larsson, 2018). All interactions increase a content's reach and fostering interaction might be seen as the main objective of elite actors on the platforms (e.g., Kelm, 2020). There are, however, qualitative differences. Reactions, especially the fine-grained range of "emotions" provided by Facebook to respond to content, are often ambivalent, making them hard to interpret (e.g., Eberl et al., 2020). Moreover, it is not certain that the reacting users are aware that their actions increase the content's reach. On the other hand, sharing is a deliberate act of forwarding information to people in one's network. Commenting implies the most commitment from users, as they not only react or share but actively express their opinion towards a topic in public space (e.g., Salgado \& Bobba, 2019). Overall, however, it is important to note that social media engagement is an indication of involvement and participation, which does not allow us to derive any conclusions about the underlying notions of users regarding the legitimacy of the EU as such.

A growing body of literature assesses what news content characteristics trigger user engagement on social media. Derived from news values theory (Harcup \& O'Neill, 2017), news characteristics and social media users' responses are commonly discussed in terms of shareworthiness (e.g., Trilling et al., 2017). To this end, studies provide evidence that news values play a role in user engagement with news content on social media platforms (Kilgo et al., 2020; Trilling et al., 2017). Regarding EU news, social media user engagement has been subject to limited empirical research but suggests that users react to how an issue is framed in EU news texts (Galpin \& Trenz, 2019). However, little is known about what EU news characteristics trigger other forms of engagement.

Based on these considerations, we now turn to sketch hypotheses to guide our analyses. Given the scarcity of research on the topic, we draw on analyses of EU media coverage, as well as the general literature on news values and shareworthiness as to how characteristics of news content may influence user engagement on social media. We focus on four major aspects shown to be important to EU news (Boomgaarden \& De Vreese, 2016; Boomgaarden et al., 2013; Marquart et al., 2018) or news values and shareworthiness in general (Galtung \& Ruge, 1965, García-Perdomo et al., 2018; Harcup \& O’Neill, 2017; Salgado \& Bobba, 2019; Shoemaker, 1996; Trilling et al., 2017; Ziegele et al., 2014; Ziegele \& Quiring, 2013). Information that is eas- ily brought to one's mind is more likely to be shared; indeed, the proximity aspect is a crucial predictor of news-and shareworthiness, including in research concerned with the EU in particular (Boomgaarden et al., 2013; García-Perdomo et al., 2018; Harcup \& O’Neill, 2017; Trilling et al., 2017). Rooted in evolutionary psychology, the news values of conflict and negativity have repeatedly been found central to news values and indicators of shareworthiness (García-Perdomo et al., 2018; Harcup \& O'Neill, 2017; Karnowski et al., 2021), including in studies of EU news (Boomgaarden et al., 2013; Gattermann, 2013). Finally, the emotionality of news content is often studied in analyses of shareworthiness (García-Perdomo et al., 2018) and represents an important news value (Harcup \& O'Neill, 2017). To our best knowledge, it has not received attention in EU studies. Our research, thus, extends the debate by including it in the analysis.

Proximity. The EU is still perceived as rather remote, complex, and fundamentally different from the nationstate in how political decision-making is organized. The national system, in contrast, is often used as a proxy to explain the complicated legislative processes at the EU level (Gattermann, 2013). Domestification or geographical proximity is generally among the factors making news more newsworthy (Harcup \& O'Neill, 2017) and more shareworthy on social media (García-Perdomo et al., 2018; Trilling et al., 2017). A strong domestic angle is also a persistent pattern in EU news coverage (e.g., Boomgaarden et al., 2013; Eisele, 2017). Moreover, news about other EU member states (horizontal Europeanization) rather than about the EU and its institutions (vertical Europeanization) are expected to induce more engagement (see Koopmans \& Erbe, 2004 for an elaboration on Europeanization). Larger member states, neighboring countries, or other EU countries with cultural ties or a shared language may stand out as being more relevant to the readership (e.g., Gattermann, 2013; Walter, 2016). In terms of relevance and anticipated engagement, thus, we can distinguish degrees of geographical or political proximity, with EU news being most distant when they are about the EU as such, less distant when they are about other EU member states, bordering countries, and closest when they deal with Austrian EU politics. Against this background, we expect that:

$\mathrm{H} 1$ : The greater the proximity of EU news, the more it prompts engagement by social media users.

Conflict. Conflict has repeatedly been found to be a strong news value (e.g., Schultz, 2007). Regarding the EU as a news topic, the conflicts resulting from policy responses to EU crises, mirrored in a surge of Euroskepticism in party systems, the media, and public opinion (Boomgaarden \& De Vreese, 2016; Hobolt \& De Vries, 2016; Marquart et al., 2018), have increased the EU's presence on the media agenda (e.g., Boomgaarden et al., 2013). Also, in analyses of 
social media user engagement, conflict has been identified as a prominent characteristic of shared stories (García-Perdomo et al., 2018; Harcup \& O’Neill, 2017). Accordingly, we expect that:

$\mathrm{H} 2$ : The more prominently conflict is discussed in EU news, the more it prompts engagement by social media users.

Negativity. The negativity of news is an important news value (Harcup \& O'Neill, 2017). EU news, in particular, is found to have increased, but negatively so (Marquart et al., 2018). As with conflict, this increase in negativity is mostly attributed to a decade of crises during which issues such as austerity policies and increasing unemployment rates, as well as an unprecedented number of refugees, increased public criticism. Moreover, negativity is also a strong predictor of user engagement on social media (García-Perdomo et al., 2018; Salgado \& Bobba, 2019; Trilling et al., 2017). Against this backdrop, we expect that:

H3: The more negatively EU news is discussed, the more it prompts engagement by social media users.

Emotionality. Often shared news items on social media have been described as "stuff that makes you laugh and stuff that makes you angry" (Gibson quoted in Newman, 2011 , p. 24), highlighting the importance of emotional appeals for the shareworthiness of news (Berger \& Milkman, 2012; Harcup \& O'Neill, 2017). Accordingly, studies find that emotional content is engaged with on social media to a greater extent (Berger, 2011; Salgado \& Bobba, 2019). We thus expect that:

$\mathrm{H} 4$ : The more emotionally EU news is discussed, the more it prompts engagement by social media users.

\section{Methodology}

\subsection{Case Selection}

Politically, Austria is an interesting case regarding the dynamics between the national and the EU level. Especially the migration crisis of 2015/2016 shook the political system, causing deep conflicts (Auel \& Pollak, 2016). Moreover, the rather small news market allows for a comprehensive analysis of (almost) all-important news outlets. Despite being a small country, Austrian newspapers dominate the print segment, with almost no "imported" newspapers from other German-speaking markets (e.g., Newman et al., 2021).

Shareworthiness on Facebook is a major factor for newsmakers to consider, and accordingly, Facebook is driving most traffic in online news (Harcup \& O'Neill, 2017). In Austria, Facebook is the most popular social media site, used by around $31 \%$ for news consumption and $60 \%$ overall (Newman et al., 2021), this being why we decided to analyze Facebook rather than, for example, Twitter: The Austrian Twittersphere is described as rather elitist, populated by journalists and politicians and only used by $5 \%$ of Austrians for news consumption (e.g., Maares et al., 2021; Newman et al., 2021).

\subsection{Data Collection}

We analyzed EU news, operationalized as news content about the EU and its institutions, actors, and key policies. We collected news articles published between 2015 and 2019 in 12 Austrian newspapers as well as the status posts from their official Facebook accounts. We queried the API of the Austrian Press Agency to retrieve the news articles (see Table 1 ). All outlets were selected based on their reach, journalistic routines, and scope of distribution, presenting a good cross-section of the Austrian press. We then compiled a search string to identify articles that deal with the EU (Please see Section A1 in the Supplementary Material for the complete search string used to retrieve articles). The search string was created relying on existing studies, the expert knowledge of the authors, and terms stemming from the manual inspection of a random sample of 875 articles. Using a fresh random sample of 1,500 news articles, the search string was validated by three independent manual coders (Krippendorff's $\alpha=0.86$ ), reaching satisfactory performance scores (precision $=0.92$, recall $=0.96, \mathrm{~F} 1=0.94)$. A python script was used to collect the data, gathering the textual content and metadata of $N=258,704$ EU-related news articles.

Similarly, we collected all status posts published by the Facebook accounts of the news outlets via CrowdTangle (see Table 1). Gathering textual content (i.e., captions), associated metadata (e.g., date, URL), and user interaction information (number of reactions, shares, and comments), we collected a total of $N=570,700$ status posts.

\subsection{Content Matching/Tracing}

As Facebook does not provide any information beyond a "caption" (comparable to the article's headline) of the external resource (e.g., a news article), both data sources needed to be connected to enable the linkage of Facebook user engagement and news content. Thus, we compared captions used by news outlets to advertise articles on Facebook with the headlines of the items in the news media data. While some outlets use identical texts for both, others alter (e.g., shorten) it slightly on the social media platform. We used cosine similarity to account for marginal differences. We manually inspected matched texts by comparing different thresholds considering the number of matches and the shared semantic meaning. Texts (i.e., pairs of headlines from the news media data and captions from the Facebook data) that exhibited a cosine similarity of 0.8 or higher were defined as matching, indicating that a status post 
Table 1. News and Facebook data.

\begin{tabular}{lccc}
\hline Outlet & $\begin{array}{c}\text { Number of EU-related } \\
\text { News Articles }\end{array}$ & $\begin{array}{c}\text { Number of Facebook } \\
\text { Status Posts }\end{array}$ & Matched (\% of all articles) \\
\hline Der Standard & 31,772 & 69,847 & $1,495(4.71)$ \\
Die Presse & 31,121 & 47,088 & $1,860(5.98)$ \\
Heute & 4,858 & 54,356 & $82(1.69)$ \\
Kleine Zeitung & 23,716 & 55,764 & $125(0.53)$ \\
Kronen Zeitung & 30,352 & 54,317 & $304(1)$ \\
Kurier & 33,611 & 58,367 & $1,685(5.01)$ \\
Oberösterreichische Nachrichten & 20,324 & 33,820 & $537(2.64)$ \\
Österreich & 11,230 & 82,562 & $1,185(10.55)$ \\
Salzburger Nachrichten & 17,586 & 33,455 & $505(2.87)$ \\
Tiroler Tageszeitung & 21,586 & 46,437 & $718(3.33)$ \\
Vorarlberger Nachrichten & 10,926 & 9,432 & $570(5.22)$ \\
Wiener Zeitung & 21,622 & 25,255 & $1,704(7.88)$ \\
\hline Total & 258,704 & 570,700 & $10,770(4.16)$ \\
\hline
\end{tabular}

refers to an article and thus user interactions can be seen as a response to this news content (e.g., Trilling et al., 2017). In total, we connected 10,770 (4.16\%) of the 258,704 EU-related articles to a status post (see Table 1 ).

\subsection{Independent Variables: Content Analysis}

We analyzed news articles about the EU in terms of proximity, conflictuality, negativity, and emotionality, using the semi-supervised approaches Newsmap (Watanabe, 2018) and Latent Semantic Scaling (LSS; Watanabe, 2020). While the former automatically constructs a machine learning classifier to detect relations to a country starting from a small dictionary, the latter computes semantic proximity of words in a corpus based on a set of "seed words" that the authors selected manually to define the dimensions of interest.

Proximity. Proximity is here operationalized as the angle promoted in news content about the EU: All analyzed news, thus, is about the EU while the analysis of proximity indicates whether the article is dealing with, e.g., national EU politics rather than genuine news about the EU institutions (vertical Europeanization). We used the R package Newsmap (Watanabe, 2018) and applied a machine-learning algorithm to identify the country with which a news article is mostly concerned. Given that not all articles deal with a single country, countryspecific topics, or countries per se, we extracted the likelihood ratio. Articles not reaching a qualitatively determined threshold of 0.5 and articles dealing with non-EU countries were labelled as "EU level." Furthermore, the measure classifies articles dealing with specific EU countries that are not neighboring states to Austria, adjacent states, or Austria itself.

Conflictuality, negativity, and emotionality. To measure these concepts, we relied on the LSS approach and the $\mathrm{R}$ package LSX (Watanabe, 2020). Applying LSS, we estimated the semantic proximity of words in the news corpus, selected words that frequently occurred in the immediate context of the EU and weighted them based on their semantic proximity to 5 seed words for each dimension (Table 2). We selected seed words primarily based on our background knowledge but also referred to existing resources such as the augmented German sentiment dictionary (for negativity; Rauh, 2018) and Affective Norms for German Sentiment Terms (ANGST, for emotionality; Schmidtke et al., 2014). In addition to the theoretical angle provided by expert assessment and prior studies, we also ensured that the seed words were relevant to the corpus, checking for a reasonable number of occurrences within the data. As seeds for LSS are bipolar, we furthermore gathered terms indicating the opposite of the three concepts (see Table 2).

Subsequently, we assigned scores for each article as a weighted average of the polarity scores using the fitted LSS models. To assess the accuracy, we compared the scores computed by LSS against manually assigned scores of up to 2,314 articles. We ensured that the measurement errors cancel out each other following earlier studies (for comparable approaches, see Trubowitz \& Watanabe, 2021; Young \& Soroka, 2012), taking the mean scores of articles in three-month windows. The correlation between the LSS and manual coding reaches satisfactory levels for conflictuality $(r=0.79)$, negativity $(r=0.7)$, and emotionality $(r=0.62$; see Figure 1).

\subsection{Dependent Variables: User Engagement}

Our dependent variables concern the counts of all forms of engagement (i.e., all interactions) the platform provides. For all articles in our print media data that could be linked to a Facebook status post, we define the following three variables.

Reactions. Facebook provides a nuanced set of reactions to respond to content on its platform. Users may choose between emoji-like reactions "like," "love," "haha," "wow," "sad," and "angry." However, the only 
Table 2. Seed words for conflictuality, negativity, and emotionality.

Conflictuality

Conflict

streit, drohung, konflikt, dissens, verbündete (dispute, threat, conflict, dissent, allies)

\section{Agreement}

stille, ruhe, harmonie, verbundenheit, eintracht

(silence, calm, harmony, connectedness, concord)

\begin{tabular}{lc}
\hline \multicolumn{1}{c}{$\begin{array}{l}\text { Negative } \\
\text { korruption, anmaßung, beschämend, fehler, terror }\end{array}$} & Negativity \\
(corruption, hubris, disgrace, mistake, terror) & $\begin{array}{l}\text { gerechtigkeit, möglichkeit, erfolgreich, verhandlung, gut } \\
\text { (justice, opportunity, success, negotiation, good) }\end{array}$
\end{tabular}

Emotionality

\section{Emotional}

freiheit, abenteuer, bevormundung, euphorie, lebendig (freedom, adventure, paternalism, elation, alive)

\section{Factual}

wissenschaft, fakt, anzahl, prozent, akkurat, (percent, accurate, science, fact, quantity)

Note: English translations of the words in parentheses.

reaction available to users through our entire period of the analysis is "like," as more detailed reactions were not introduced until January 2016. The main commonality for all these reactions is that they depict low-threshold forms of engagement (Salgado \& Bobba, 2019). As we aim to map the entirety of users' engagement, we use a combined measure of reactions (see Heidenreich \& Eberl, 2021, for a similar approach). Before 2016, this includes only "like," whereas from January 2016 onward, this variable is composed of the sum of "like," "love," "haha," "wow," "sad," and "angry" reactions.

Shares. The second form of engagement concerns the sharing behavior of users. Representing the intermediate category of commitment needed to engage with content on social media (Alhabash \& McAlister, 2015), sharing means the active forwarding of information to peers (i.e., friends).

Comments. Lastly, we investigate the deliberative aspect of comments, the form of engagement involving the highest commitment of users (Salgado \& Bobba, 2019). Here, we record the number of comments in response to a status post referencing an EU-related news article. While individual users can share or interact with a status post only once, commenting is an action that can be performed multiple times by a single person.

\subsection{Analytical Strategy: Negative Binomial Regression Model}

As the dependent variables are count data that are assumed to stem from an overdispersed Poisson distribution (e.g., variance being much larger than the mean), we implement negative binomial regression models for the analyses. Using the R package brms (Bürkner, 2017), hierarchical, varying intercepts models with parameters computed from 3,000 Markov Chain Monte Carlo samples were estimated. The data were clustered on the outlet level, accounting for users reacting to specific coverage styles differently, and the length of an article was added as a control variable. All models converged properly with $R$ hat never exceeding 1.01 (Gelman \& Rubin, 1992), MCMC trace plots can be found in the Supplementary Material (see Figure A1 to A3 in the Supplementary Material).
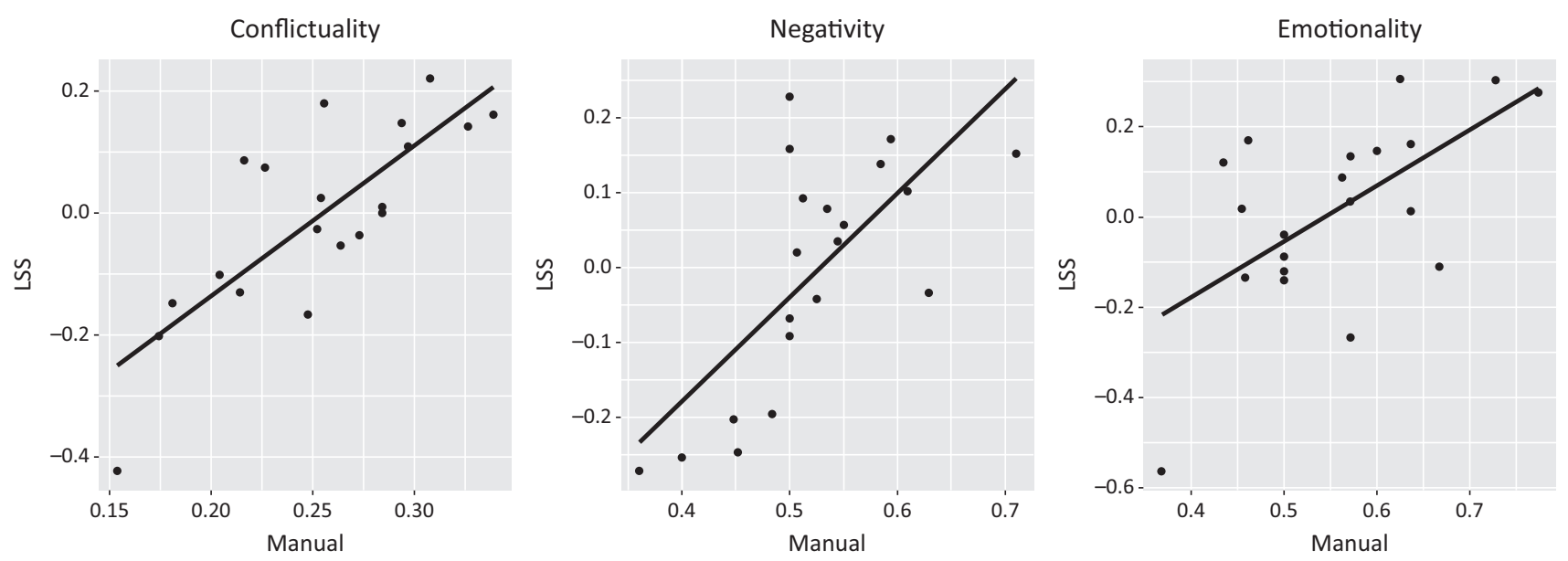

Figure 1. Correlation LSS scores and manual coding. 


\section{Results}

We find that, in general, EU-related news elicit distinctly less engagement from users than other news. While we cannot speak of the content of other news coverage, we find that EU-related articles are shared approximately half as much as non-EU-related news (11.34 to 20.33; see Table 3 ). Although differences are not equally outspo- ken concerning comments ( 34.45 to 40.87 ) and reactions (75.36 to 118), similar patterns can be observed.

Our first assumption that greater proximity leads to increased engagement does, overall, find mixed empirical support. In line with $\mathrm{H} 1$, our results show positive coefficients (see Figure 2 or Table $A 1$ in the Supplementary Material), especially for reactions and comments if an article deals mainly with Austria. While

Table 3. User interactions.

\begin{tabular}{|c|c|c|c|c|c|c|c|c|}
\hline \multirow[b]{2}{*}{ Engagement type } & \multicolumn{4}{|c|}{$\begin{array}{l}\text { Status Posts referring to } \\
\text { EU-related news articles }\end{array}$} & \multicolumn{4}{|c|}{$\begin{array}{c}\text { Status Posts referring to } \\
\text { non-EU-related news articles }\end{array}$} \\
\hline & Mean & SD & Min & Max & Mean & SD & Min & Max \\
\hline Share & 11.34 & 35.55 & 0 & 1,119 & 20.33 & 106.44 & 0 & 41,426 \\
\hline Comment & 34.45 & 70.98 & 0 & 929 & 40.87 & 102.73 & 0 & 15,161 \\
\hline Like 目 & 61.36 & 323.26 & 0 & 12,266 & 77.42 & 319 & 0 & 119,044 \\
\hline Love $\bigcirc$ & 1.46 & 7.43 & 0 & 309 & 2.57 & 25.6 & 0 & 7,892 \\
\hline Haha & 7.52 & 26.81 & 0 & 837 & 10.21 & 42.33 & 0 & 3,940 \\
\hline Wow & 1.41 & 5.53 & 0 & 297 & 4.5 & 17.1 & 0 & 2,435 \\
\hline Sad $\Theta$ & 2.4 & 11.2 & 0 & 364 & 8.91 & 52.32 & 0 & 7,000 \\
\hline Angry $\Theta$ & 8.62 & 38.28 & 0 & 891 & 14.38 & 68.79 & 0 & 5,080 \\
\hline Total Reactions & 75.36 & 303.57 & 0 & 12,653 & 118 & 362.92 & 0 & 119,044 \\
\hline$N$ & \multicolumn{4}{|c|}{10,380} & \multicolumn{4}{|c|}{560,320} \\
\hline
\end{tabular}
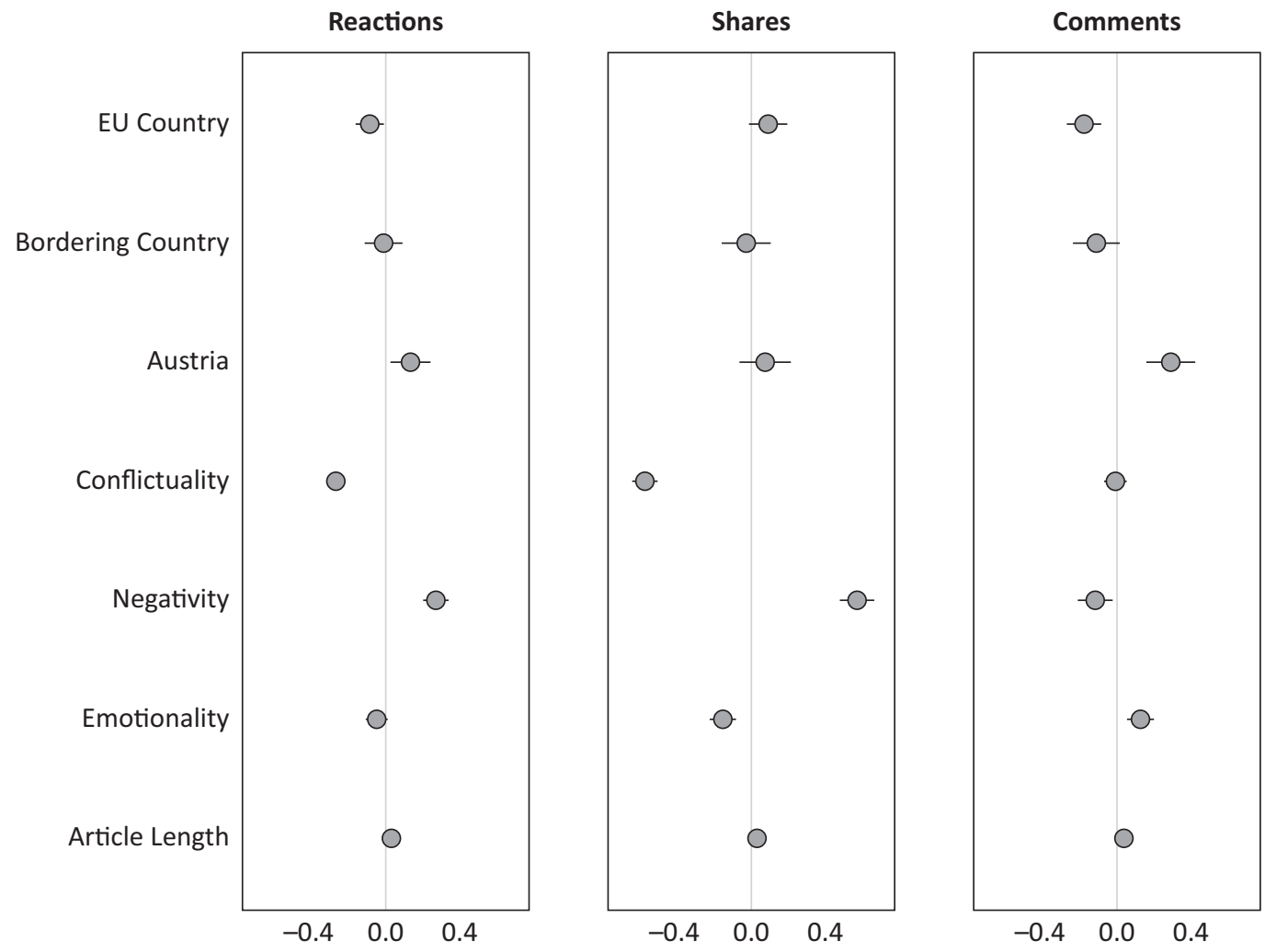

Figure 2. Estimated posterior fixed-effects parameters for reactions, shares, and comments. Notes: Means of posterior samples are represented as dots; thick and thin lines represent $50 \%$ and $95 \%$ credible intervals, respectively; figures are based on the models for reactions, shares, and comments of Table A1 in the Supplementary Material; $N=10,380$ for all three models. 
this is also true for shares when articles address EU countries that are not Austria or its adjacent states, all other coefficients indicate that engagement does not increase compared to articles dealing with non-EU countries (reference category).

Furthermore, we find no support for $\mathrm{H} 2$ : While we assumed increased conflictuality to elicit more user engagement, findings reveal that the opposite is true for reactions and shares, with the latter distinctly decreasing the more the conflict is discussed. H3, in turn, is partially confirmed: Negativity in EU news does increase engagement regarding reactions, shares, but not commenting. Lastly, we expected more emotional language to trigger user engagement $(\mathrm{H} 4)$ which is not entirely supported by our findings. Greater emotionality rather decreases reactions and shares, whereas users are more inclined to comment on such articles.

Please note that in addition to the main analyses shown here, we ran models cutting off the top $1.5 \%$ cases regarding reactions, shares, and comments, respectively, to demonstrate the robustness of our findings. The results of these supplementary models can be found in Table A2 in the Supplementary Material.

\section{Conclusions}

This study set out to further our understanding of which characteristics of EU news content would elicit user engagement on social media. Given the backdrop of the alleged participation deficit, lack of public interest, and increasing public skepticism towards the EU in many countries (Baglioni \& Hurrelmann, 2016; de Wilde et al., 2014; Hobolt \& De Vries, 2016; Marquart et al., 2018), it appears vital to assess how elite communication through the news media might encourage citizens to engage with EU politics.

Our findings show that, indeed, many of the common factors that explain the shareworthiness of news (e.g., Trilling et al., 2017) or user engagement with news on social media more generally (e.g., Kilgo et al., 2020) also do well in explaining social media users' interactions with EU news. More specifically, however, the actual directions of influences do not always confirm our expectations. This may suggest that EU news might indeed be different from other types of news in the eyes of the audience, a difference that sometimes is postulated in the literature on media and European integration (Boomgaarden et al., 2013) and that forms of engagement might need to be differentiated in more detail.

Overall, users' engagement with EU news was much lower than status posts referring to other topics. This is hardly surprising for a topic that is repeatedly found to be complex and characterized by the remoteness from citizens' everyday political experiences (e.g., Gattermann, 2013; Gattermann et al., 2021; Marquart et al., 2018). We found that negativity caused significantly more reactions and sharing (in line with $\mathrm{H} 3$ ), but not commenting where the effect is reversed. As discussed above, com- menting is the qualitatively most cognitively demanding type of social media interaction (Salgado \& Bobba, 2019). Results may suggest that users are less inclined to enter debates that are already negative. They do, however, not shy away from sharing such content with others or reacting to it, willingly or unwillingly contributing to the spread of negative discourses. Drawing on earlier research (de Wilde et al., 2014; see also Galpin \& Trenz, 2019), moreover, the actual contents of comments on EU news are likely to be negative and overall characterized by a populist anti-elite opposition targeting the EU as such instead of a differentiated critical view of selected policies (see also Gattermann et al., 2021 for a discussion of this argument in the context of EU elections). Thus, even though we do not find positive effects on the volume of comments, negativity seems crucial in terms of social media engagement with EU news. Moreover, we found that both conflict and emotionality mostly reduce engagement, contrary to our expectations ( $\mathrm{H} 2$ and $\mathrm{H} 4)$. For emotionality, it seems that, in contrast to negativity, more emotional language may not lead to more reactions and shares but animates users to bring in their perspectives. These findings may be read as positive signs for European integration since news inhibiting conflict regarding the EU does not lead to more social media engagement. Yet, conflict in traditional news was also shown to mobilize people (Schuck et al., 2016). Again, reading this against the background of earlier research, conflict regarding the $\mathrm{EU}$ and its policies or institutions might already represent a more fine-grained discussion than a generalized, "populist" opposition to the EU as an elite project would be willing to accommodate (Galpin \& Trenz, 2019). The most negative effect of emotionality, then, seems good news from the perspective of deliberative democracy, emphasizing the rational, civil, reason-based, i.e., unemotional, exchange of arguments in public discourse (Habermas, 1962). However, it triggers users to comment on EU news which is seen as the most demanding form of engagement. Coupled with the positive effect for negativity and the analyses of comments conducted in earlier research (e.g., Galpin \& Trenz, 2019), it seems that social media engagement with EU news is mainly driven by negativity. Engagement, thus, seems firmly rooted in generalized Euroscepticism (e.g., de Wilde et al., 2014), further aroused by an emotional framing of EU news.

The effects of proximity show that a focus on other EU countries (reactions and commenting) leads to significantly less engagement than genuine EU news. Results are, moreover, in line with our expectation (H1) in that the usually prevailing national angle found in traditional EU media coverage (e.g., Boomgaarden et al., 2013) does indeed lead to more social media engagement: We find a positive effect, especially for reacting and commenting. Against the background of the often discussed increasing "audience logic" of digital journalism (e.g., Blassnig \& Esser, 2021), it is thus not surprising that journalists still adhere to their focus on the national implications 
of EU politics. The greater engagement with national EU news perpetuates the national focus, and thus a Europeanization of public spheres along national borders, a finding which aligns with earlier research comparing Facebook and Twitter (Bossetta et al., 2017). While this result is in line with our expectations, our findings might mirror the specific affordances of Facebook as a communication platform rather than a general representation of how social media users engage with EU news. It thus merits further investigation.

As research on social media in general, our study is not without challenges and limitations. While companies are about to provide researchers with more and more unrestricted access to social media data, gathering communication from the platforms can still be difficult or even impossible, especially when it comes to sites outside of the "usual spectrum" (i.e., Twitter and Facebook). In addition, platform providers nowadays emphasize data protection more than in prior years (and rightfully so), imposing restrictions on access to certain data that could expand the possibilities of social science research and deepen our understanding of dynamics. In the context of this study, this particularly concerns the actual comments. It is currently impossible to gather information on this aspect, barring any research on the actual contents posted in response to status posts. Therefore, research questions interested in unveiling more fine-grained dynamics targeting users' contributions cannot be addressed now. This also means that we cannot assess what the engagement with EU news, as operationalized in this study, might mean in terms of legitimacy or support for the EU as such. Moreover, social media communication is often heavily focused on visual content, which could also help explain the users' engagement (e.g., Farkas \& Bene, 2021). Studies that only focus on textual elements thus might neglect one important aspect of communication on these platforms. Lastly, we need to acknowledge that the interpretation of the different forms of engagement remains somewhat ambiguous. Although initial studies show how certain reaction types may be mapped to distinct emotional responses from users or vice versa (e.g., de León \& Trilling, 2021; Eberl et al., 2020; Jost et al., 2020; Zerback \& Wirz, 2021), it is not entirely clear how responses such as certain Facebook reaction types (e.g., "haha" or "wow"), sharing, or the context-less act of commenting should be interpreted. Results from such studies, thus, need to be assessed with caution or put into a broader context as we did in this study.

In addition to these general challenges coming with the investigation of social media content, this research faced further limitations. First, the linking of media content with Facebook posts appeared to be challenging. As journalists vary the content for social media, headlines are not one-to-one matchable, complicating the linkage of data. While we tried our best to assure that media content was indeed associated with a respective status post on Facebook, the approach linking both data sources using a cosine similarity measure does not come without errors. Future research, thus, may implement qualitative approaches to reproduce the findings of our study. Second, the measurement of conflictuality, negativity, and emotionality using LSS (Watanabe, 2020) is heavily dependent on pre-processing steps as well as seed word selection. Guided by existing sources of semantically loaded terms, we tried to choose seed words systematically, yet the limited selection might not always reflect the spectrum of the respective concepts as defined in prior studies. However, with the scaling approach accounting for this aspect and the comparison to our manually coded data, we are confident that our measures do indeed pick up the concepts as intended. Third, our study is largely exploratory in that it focuses only on general EU news on Facebook. Future research should add to the debate by comparing platforms and distinguishing the different issues discussed in the news, which would deepen our understanding of what topics drive user engagement and how different platforms influence it.

Despite the limitations mentioned, our study provides a unique, comprehensive perspective on how elite communication from newspapers may trigger public engagement in general and for the EU. It thereby informs the debate about the EU's participation deficit and its contested democratic credentials. Our study resonates with earlier research in that it finds results converging on Euroscepticism. Nonetheless, it also opens interesting avenues for future research and may, thereby, help to spark a broader academic debate on citizens' social media engagement with the EU.

\section{Acknowledgments}

The authors would like to acknowledge the funding of the Austrian Science Fund in the Hertha Firnberg program (Grant No. T-989) for Olga Eisele and the Anniversary Fund of the Austrian National Bank (Grant No. 18120) for Tobias Heidenreich.

\section{Conflict of Interests}

The authors declare no conflict of interest.

\section{Supplementary Material}

Supplementary material for this article is available online in the format provided by the author (unedited).

\section{References}

Alhabash, S., \& McAlister, A. R. (2015). Redefining virality in less broad strokes: Predicting viral behavioral intentions from motivations and uses of Facebook and Twitter. New Media \& Society, 17(8), 1317-1339.

Auel, K., \& Pollak, J. (2016). Österreich. In W. Weidenfeld \& W. Wessels (Eds.), Jahrbuch der Europäischen Integration 2016 [Yearbook of European integration 
2016] (Vol. 1, pp. 547-552). Nomos.

Baglioni, S., \& Hurrelmann, A. (2016). The eurozone crisis and citizen engagement in EU affairs. West European Politics, 39(1), 104-124.

Barisione, M., \& Michailidou, A. (2017). Social media and European politics: Rethinking power and legitimacy in the digital era. Palgrave Macmillan.

Bennett, W. L., \& Pfetsch, B. (2018). Rethinking political communication in a time of disrupted public spheres. Journal of Communication, 68(2), 243-253.

Berger, J. (2011). Arousal increases social transmission of information. Psychological Science, 22(7), 891-893.

Berger, J., \& Milkman, K. L. (2012). What makes online content viral? Journal of Marketing Research, 49(2), 192-205.

Blassnig, S., \& Esser, F. (2021). The "audience logic" in digital journalism: An exploration of shifting news logics across media types and time. Journalism Studies. Advance online publication.

Bode, L. (2016). Political news in the news feed: Learning politics from social media. Mass Communication and Society, 19(1), 24-48.

Boomgaarden, H. G., \& De Vreese, C. H. (2016). Do European elections create a European public sphere? In W. Van der Brug \& C. H. De Vreese (Eds.), (Un)intended consequences of European Parliamentary elections (Vol. 1, pp. 19-35). Oxford University Press.

Boomgaarden, H. G., De Vreese, C. H., Schuck, A. R. T. T., Azrout, R., Elenbaas, M., Van Spanje, J. H. P. P., \& Vliegenthart, R. (2013). Across time and space: Explaining variation in news coverage of the European Union. European Journal of Political Research, 52(5), 608-629.

Bossetta, M., Dutceac Segesten, A., \& Trenz, H.-J. (2017). Engaging with European politics through Twitter and Facebook: Participation beyond the national? In $\mathrm{M}$. Barisione \& A. Michailidou (Eds.), Social media and European politics (pp. 53-76). Palgrave Macmillan.

Bürkner, P. C. (2017). brms: An R package for Bayesian multilevel models using Stan. Journal of Statistical Software, 80(1), 1-28.

Cinalli, M., Trenz, H.-J., Brändle, V., Eisele, O., \& Lahusen, C. (2021). Solidarity in the media and public contention over refugees in Europe. Taylor \& Francis.

de León, E., \& Trilling, D. (2021). A sadness bias in political news sharing? The role of discrete emotions in the engagement and dissemination of political news on Facebook. Social Media+ Society, 7(4). https:// doi.org/10.1177\%2F20563051211059710

de Wilde, P., Michailidou, A., \& Trenz, H.-J. (2014). Converging on Euroscepticism: Online polity contestation during European Parliament elections. European Journal of Political Research, 53(4), 766-783.

Eberl, J. M., Tolochko, P., Jost, P., Heidenreich, T., \& Boomgaarden, H. G. (2020). What's in a post? How sentiment and issue salience affect users' emotional reactions on Facebook. Journal of Information Tech- nology \& Politics, 17(1), 48-65.

Eisele, O. (2017). Complementing, competing, or co-operating? Exploring newspapers' portrayals of the European Parliament and national parliaments in EU affairs. Journal of European Integration, 39(4), 435-451.

Ekman, M. (2019). Anti-immigration and racist discourse in social media. European Journal of Communication, 34(6), 606-618.

Farkas, X., \& Bene, M. (2021). Images, politicians, and social media: Patterns and effects of politicians' image-based political communication strategies on social media. The International Journal of Press/Politics, 26(1), 119-142.

Fazekas, Z., Popa, S. A., Schmitt, H., Barberá, P., \& Theocharis, Y. (2021). Elite-public interaction on Twitter: $\mathrm{EU}$ issue expansion in the campaign. European Journal of Political Research, 60(2), 376-396.

Galpin, C., \& Trenz, H.-J. (2019). Participatory populism: Online discussion forums on mainstream news sites during the 2014 European Parliament election. Journalism Practice, 13(7), 781-798.

Galtung, J., \& Ruge, M. H. (1965). The structure of foreign news: The presentation of the Congo, Cuba and Cyprus crises in four Norwegian newspapers. Journal of Peace Research, 2(1), 64-90.

García-Perdomo, V., Salaverría, R., Kilgo, D. K., \& Harlow, S. (2018). To share or not to share: The influence of news values and topics on popular social media content in the United States, Brazil, and Argentina. Journalism Studies, 19(8), 1180-1201.

Gattermann, K. (2013). News about the European Parliament: Patterns and external drivers of broadsheet coverage. European Union Politics, 14(3), 436-457.

Gattermann, K., de Vreese, C. H., \& van der Brug, W. (2021). Introduction to the special issue: No longer second-order? Explaining the European Parliament elections of 2019. Politics, 41(4), 423-432.

Gelman, A., \& Rubin, D. B. (1992). Inference from iterative simulation using multiple sequences. Statistical Science, 7(4), 457-472.

Habermas, J. (1962). Strukturwandel der Öffentlichkeit. Untersuchungen zu einer Kategorie der bürgerlichen Gesellschaft [The structural transformation of the public sphere: An inquiry into a category of bourgeois society]. Suhrkamp.

Harcup, T., \& O'Neill, D. (2017). What is news? News values revisited (again). Journalism Studies, 18(12), 1470-1488.

Heidenreich, T., \& Eberl, J.-M. (2021). Political elites' migration discourses on social media. In J. Strömbäck, C. E. Meltzer, J.-M. Eberl, C. Schemer, \& H. G. Boomgaarden (Eds.), Media and public attitudes toward migration in Europe: A comparative approach (Vol. 1, pp. 140-156). Routledge.

Hobolt, S. B., \& De Vries, C. E. (2016). Public support for European integration. Annual Review of Political Science, 19(1), 413-432. 
Jost, P., Maurer, M., \& Hassler, J. (2020). Populism fuels love and anger: The impact of message features on users' reactions on Facebook. International Journal of Communication, 14(22), 2081-2102.

Karnowski, V., Leiner, D. J., Kümpel, A. S., \& Leonhard, L. (2021). Worth to share? How content characteristics and article competitiveness influence news sharing on social network sites. Journalism \& Mass Communication Quarterly, 98(1), 59-82.

Kelm, O. (2020). Why do politicians use Facebook and Twitter the way they do? The influence of perceived audience expectations. SCM Studies in Communication and Media, 9(1), 8-34.

Kilgo, D. K., Lough, K., \& Riedl, M. J. (2020). Emotional appeals and news values as factors of shareworthiness in ice bucket challenge coverage. Digital Journalism, 8(2), 267-286.

Koopmans, R., \& Erbe, J. (2004). Towards a European public sphere? Innovation: The European Journal of Social Science Research, 17(2), 97-118.

Larsson, A. O. (2018). The news user on social media: A comparative study of interacting with media organizations on Facebook and Instagram. Journalism Studies, 19(15), 2225-2242.

Maares, P., Lind, F., \& Greussing, E. (2021). Showing off your social capital: Homophily of professional reputation and gender in journalistic networks on Twitter. Digital Journalism, 9(4), 500-517.

Marquart, F., Goldberg, A. C., van Elsas, E. J., Brosius, A., \& de Vreese, C. H. (2018). Knowing is not loving: Media effects on knowledge about and attitudes toward the EU. Journal of European Integration, 41(5), 641-655.

Michailidou, A. (2008). Democracy and new media in the European Union: Communication or participation deficit? Journal of Contemporary European Research, $4(4), 346-368$.

Newman, N. (2011). Mainstream media and the distribution of news in the age of social media. Reuters Institute for the Study of Journalism. https://ora.ox. ac.uk/objects/uuid:94164da6-9150-4938-8996badfdef6b507

Newman, N., Fletcher, R., Schulz, A., Simge, A., Robertson, C. T., \& Kleis Nielsen, R. (2021). Digital news report 2021. Reuters Institute. https://reuters institute.politics.ox.ac.uk/digital-news-report/2021

Rauh, C. (2018). Validating a sentiment dictionary for German political language-A workbench note. Journal of Information Technology \& Politics, 15(4), 319-343.

Salgado, S., \& Bobba, G. (2019). News on events and social media: A comparative analysis of Facebook users' reactions. Journalism Studies, 20(15), 2258-2276.

Schmidtke, D. S., Schröder, T., Jacobs, A. M., \& Conrad, M. (2014). ANGST: Affective norms for German sentiment terms, derived from the affective norms for English words. Behavior Research Methods, 46(4), 1108-1118.

Schuck, A. R., Vliegenthart, R., \& De Vreese, C. H. (2016).
Who's afraid of conflict? The mobilizing effect of conflict framing in campaign news. British Journal of Political Science, 46(1), 177-194.

Schultz, I. (2007). The journalistic gut feeling. Journalism Practice, 1(2), 190-207.

Shoemaker, P. J. (1996). Hardwired for news: Using biological and cultural evolution to explain the surveillance function. Journal of Communication, 46(3), 32-47.

Trilling, D., Tolochko, P., \& Burscher, B. (2017). From newsworthiness to shareworthiness: How to predict news sharing based on article characteristics. Journalism and Mass Communication Quarterly, 94(1), 38-60.

Trubowitz, P., \& Watanabe, K. (2021). The geopolitical threat index: A text-based computational approach to identifying foreign threats. International Studies Quarterly, 65(3), 852-855.

Van Deth, J. W. (2016). What is political participation? In W. R. Thompson (Ed.), Oxford research encyclopedia of politics. https://oxfordre.com/politics/ view/10.1093/acrefore/9780190228637.001.0001/ acrefore-9780190228637-e-68

Vissers, S., \& Stolle, D. (2014). The internet and new modes of political participation: Online versus offline participation. Information, Communication \& Society, 17(8), 937-955.

Walter, S. (2016). A network perspective on European Union news: Explaining relationships of horizontal reporting across EU member states. Mass Communication and Society, 19(6), 715-737.

Watanabe, K. (2018). Newsmap: A semi-supervised approach to geographical news classification. Digital Journalism, 6(3), 294-309.

Watanabe, K. (2020). Latent semantic scaling: A semisupervised text analysis technique for new domains and languages. Communication Methods and Measures, 15(2), 81-102.

Welbers, K., \& Opgenhaffen, M. (2019). Presenting news on social media: Media logic in the communication style of newspapers on Facebook. Digital Journalism, $7(1), 45-62$.

Young, L., \& Soroka, S. (2012). Affective news: The automated coding of sentiment in political texts. Political Communication, 29(2), 205-231.

Zerback, T., \& Wirz, D. (2021). Appraisal patterns as predictors of emotional expressions and shares on political social networking sites. Studies in Communication Sciences, 21(1), 27-45.

Ziegele, M., Breiner, T., \& Quiring, O. (2014). What creates interactivity in online news discussions? An exploratory analysis of discussion factors in user comments on news items. Journal of Communication, 64(6), 1111-1138

Ziegele, M., \& Quiring, O. (2013). Conceptualizing online discussion value: A multidimensional framework for analyzing user comments on mass-media websites. Annals of the International Communication Association, 37(1), 125-153. 


\section{About the Authors}

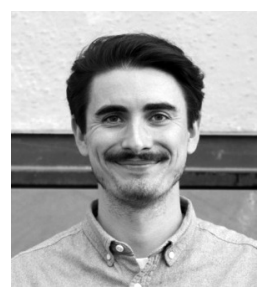

Tobias Heidenreich (PhD) is a postdoctoral research fellow at the Global Governance Department, WZB Berlin Social Science Center, and associated with the Computational Communication Science Lab at the Department of Communication, University of Vienna. His main research interests include automated content analysis methods, political communication, and social media platforms, with a particular focus on public discourse concerning the topic of migration.

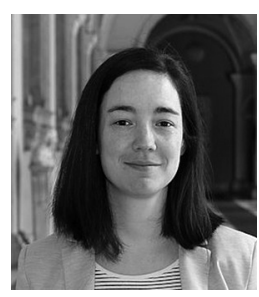

Olga Eisele $(\mathrm{PhD})$ is a Hertha-Firnberg fellow and a postdoctoral researcher at the Computational Communication Science Lab at the Department of Communication, University of Vienna. Her research interests are in political communication, revolving around the broader topic of European integration. Specifically, she focuses on political crisis communication and political legitimation processes in times of crisis, relying on automated methods of text analysis.

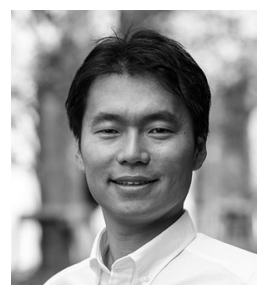

Kohei Watanabe (PhD) is an independent data analysis consultant for policy think tanks and financial companies. He is also a visiting scholar at the US Centre of the London School of Economics and Political Science and the Waseda Institute for Advanced Study. He develops R packages for quantitative text analysis that include Quanteda, LSX, and Newsmap and studies international flows of political and economic information.

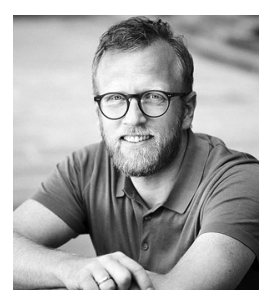

Hajo G. Boomgaarden (PhD) is a professor of empirical social science methods focusing on text analysis at the Department of Communication at the University of Vienna. His research interests include the coverage and effects of political information on citizens' cognitions, attitudes, and behaviors in various domains of media and politics, as well as developments in automated content analysis techniques. 